
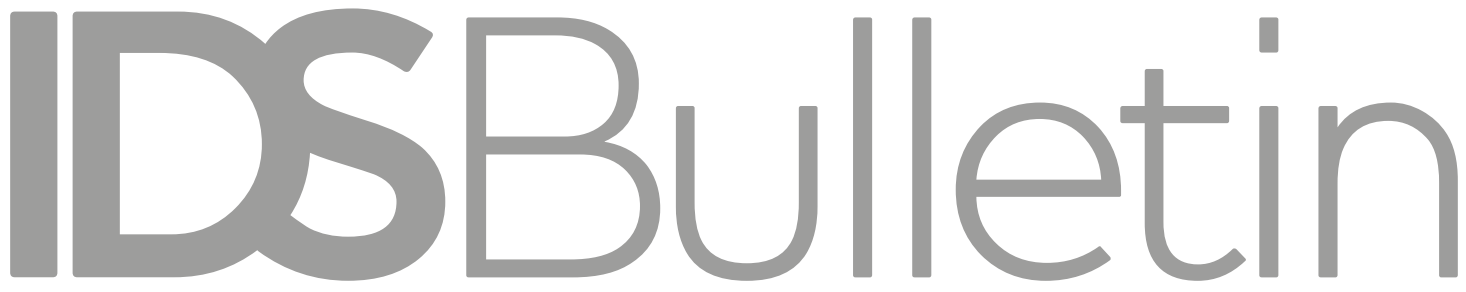

Transforming

Development Knouledge

Volume 50 | Number 2 | July 2019

\title{
THE POLITICAL \\ ECONOMY OF \\ FOOD
}

Editors Jody Harris, Molly Anderson, Chantal Clément and Nicholas Nisbett

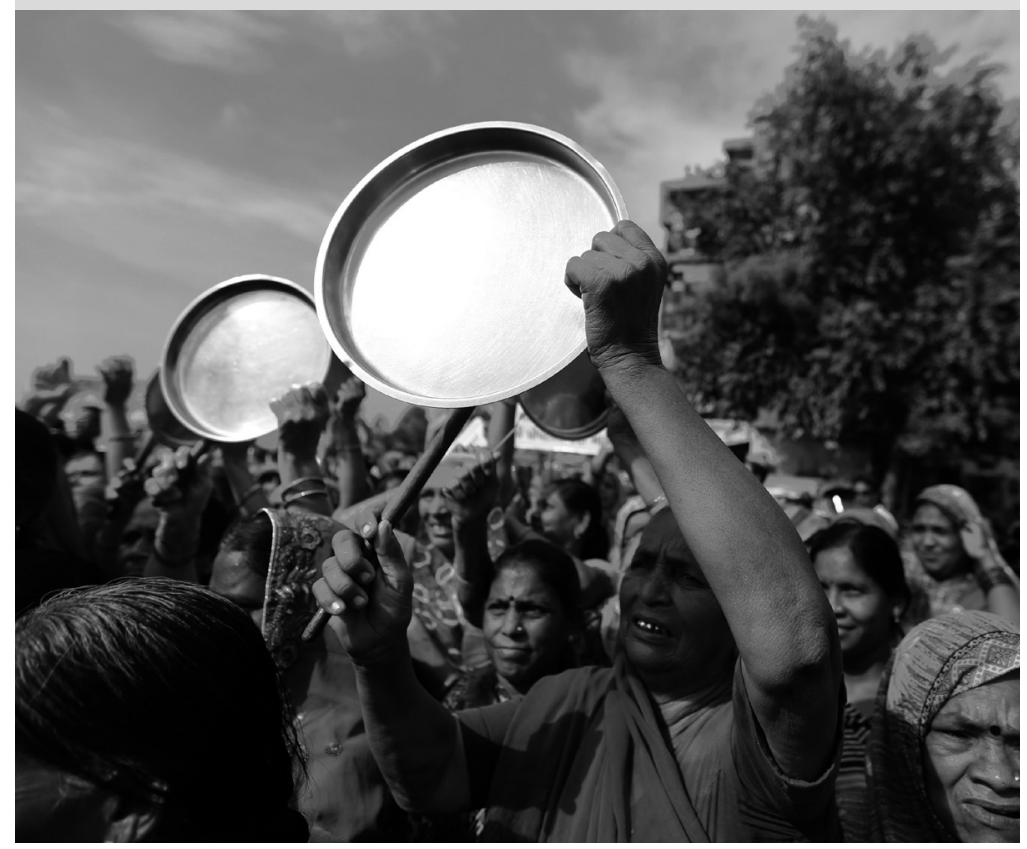


Notes on Contributors

Introduction: Valuing Different Perspectives on Power in the Food System

Molly Anderson, Nicholas Nisbett, Chantal Clément and Jody Harris

The Political Economy Approach to Food Systems Reform

Olivier De Schutter

Reflections on IPES-Food: Can Power Analysis Change the World?

Desmond McNeill

Envisioning New Horizons for the Political Economy of Sustainable Food Systems Jessica Duncan, Charles Z. Levkoe and Ana Moragues-Faus

Evidence-Based Policymaking in the Food-Health Nexus

Cecilia Rocha and Jody Harris

Purchasing and Protesting: Power from Below in the Global Food Crisis

Naomi Hossain and Patta Scott-Villiers

Agroecology and Food Sovereignty

Steve Gliessman, Harriet Friedmann and Philip H. Howard

Building a Sustainable Food City: A Collective Approach

Emily O'Brien and Nicholas Nisbett

Power in the Zambian Nutrition Policy Process

Jody Harris

Transforming Food Systems: The Potential of Engaged Political Economy Molly Anderson and Melissa Leach

Glossary 


\section{Glossary}

ACC-SCN United Nations Administrative Committee on Coordination - Sub-Committee on Nutrition [Switzerland]

ADA American Dietetic Association

AND Academy of Nutrition and Dietetics

ANSA Acuerdo Nacional para la Salud Nutricional [National

Agreement for Nutritional Health]

ASN American Society for Nutrition

CGIAR Consultative Group on International Agricultural Research

[France]

CR concentration rate

CSO Central Statistical Office [Zambia]

CSO civil society organisation

DFID Department for International Development [UK]

EEA European Environment Agency [Denmark]

ENSANUT Encuesta Nacional de Salud y Nutrición de Medio Camino [National Survey on Health and Nutrition]

EU European Union

FAO Food and Agriculture Organization of the United Nations [Italy]

GM genetically modified

HPG Humanitarian Policy Group [UK]

IAASTD International Assessment of Agricultural Knowledge, Science and Technology for Development [USA]

IEPS Impuesto Especial Sobre Producción y Servicios [Special Tax on Production and Services]

IFAD International Fund for Agricultural Development [Italy]

IIED International Institute for Environment and Development [UK]

ILC International Land Coalition [Italy]

INSP Instituto Nacional de Salud Pública [National Institute of Public Health of Mexico]

IPES International Panel of Experts on Sustainable Food Systems

[Brussels]

JSNA Joint Strategic Needs Assessment

KII key informant interview

LMU Land and Equity Movement of Uganda

MCDP Most Critical Days Programme [Zambia]

MLP Multi-Level Perspective

MoH Ministry of Health [Zambia]

NCD non-communicable disease

NFNC National Food and Nutrition Commission [Zambia]

NFNP National Food and Nutrition Policy [Zambia]

NFNSP National Food and Nutrition Strategic Plan [Zambia]

NGO non-governmental organisation

PPRR Principles, Practices, Rights, and Responsibilities

Sida Swedish International Development Cooperation Agency

SSB sugar-sweetened beverage 
STS science and technology studies

SUM Senter for utvikling og miljø [Centre for Development and the Environment, Norway]

SUN Scaling Up Nutrition

UNICEF United Nations Children's Fund [USA]

WFP World Food Programme [Italy]

WHO World Health Organization [Switzerland] 
This page is intentionally left blank 